速 報

論文受付

2011 年 11 月 14 日

論文受理

2011 年 12 月 1 日

Code Nos. 814850

\section{Radiochromic Film におけるモアレアーチファクト除去法 透過型への応用—}

辰己大作 $^{1} \quad$ 小澤修一 $^{2}$

1 大阪市立大学医学部附属病院中央放射線部

2 順天堂大学医学部放射線医学講座

\section{緒 言}

Intensity modulated radiation therapy(IMRT)などの線 量分布検証において, 現在, 現像処理を必要としない radiochromic film(RC-film)の使用が広く普及してい る。 RC-film を用いて精度良く測定を行うには，いくつ か取り扱いに注意する点がある。例として，フィルムの 保管方法, 経時的濃度変化, スキャン方向, および濃 度不均一性などが挙げられ，フラットベッドスキャナ (スキャナ)のガラス天板とフィルム面の干渉によるモア レアーチファクト(モアレ)の発生の問題もその一つであ る1 4). モアレ除去の対策については，辰己らが反射 モードでスキャンする RC-film(反射型 RC-film)につい て検討しているが4), 現在, IMRTの線量分布検証の主 流は透過モードでスキャンする RC-film(透過型 RC-film)であり5)，モアレ除去の考え方にも違いが出る 可能性がある。今回, 透過型 RC-filmに対するモアレ 除去対策について検討を行ったので報告する。

\section{1. 方 法}

透過型 RC-film として, Gafchromic EBT2(EBT2 フィルム, Lot\#: A04181102B, ISP, USA)を使用した. EBT2 フィルムに $10 \mathrm{MV}$ の X 線で, $100 \mathrm{cGy}, 125 \mathrm{cGy}$, $145 \mathrm{cGy}, 165 \mathrm{cGy}$ の 4 種類の異なる線量を照射し, 空 調の完備された暗室にて 47 日間保管後，スキャンを 行った．スキャンは沉用のフラットベッドスキャナ (ES-8500, EPSON, Japan) とフィルム読み取りソフト (Film-scan-New ver.4.0, R-Tech, Japan)を用いて行っ た。スキャン設定は, 透過原稿タイプ, イメージタイ プ : カラー $48 \mathrm{bit}$, 解像度 : $150 \mathrm{dpi}$, およびフィル夕 : $3 \times 3$ メディアンフィルタを選択し, 赤, 緑, 青(red, green, blue; RGB)の波長域に分けてデータ収集した.

モアレ除去対策の効果を確認するため，3 種類の測 定配置にてスキャンを行った。モアレ除去法は，辰己ら が報告した無反射ガラスを用いる方法を採用した4)。各 測定配置は，1) スキャナガラス天板の上に EBT2 フィル ムを置き,その上から $2 \mathrm{~mm}$ 厚の透明ガラスを配置(以

\title{
A Method for Removing Moiré Artifacts from Scanned Images of Radiochromic Films: Application to Transmissive Scanning
}

Daisaku Tatsumi ${ }^{1 *}$ and Shuichi Ozawa ${ }^{2}$

${ }^{1}$ Department of Radiology, Osaka City University Hospital

${ }^{2}$ Department of Radiology, Juntendo University School of Medicine

Received November 14, 2011; Revision accepted December 1, 2011

Code Nos. 814850

\section{Summary}

Dose verification using radiochromic films may bring about moiré artifacts during the film scanning process using a flatbed scanner. A method for removing the moiré artifacts was already reported for reflective scanning. Recently, transmissive scanning using EBT2 films has played a major role for dose verification in intensity-modulated radiation therapy. It was found that placing a nonreflecting glass plate on the detector side could eliminate all the moiré artifacts for transmissive scanning.

Key words: radiochromic film, gafchromic film, EBT2, moiré artifact, flatbed scanner

* Proceeding author 


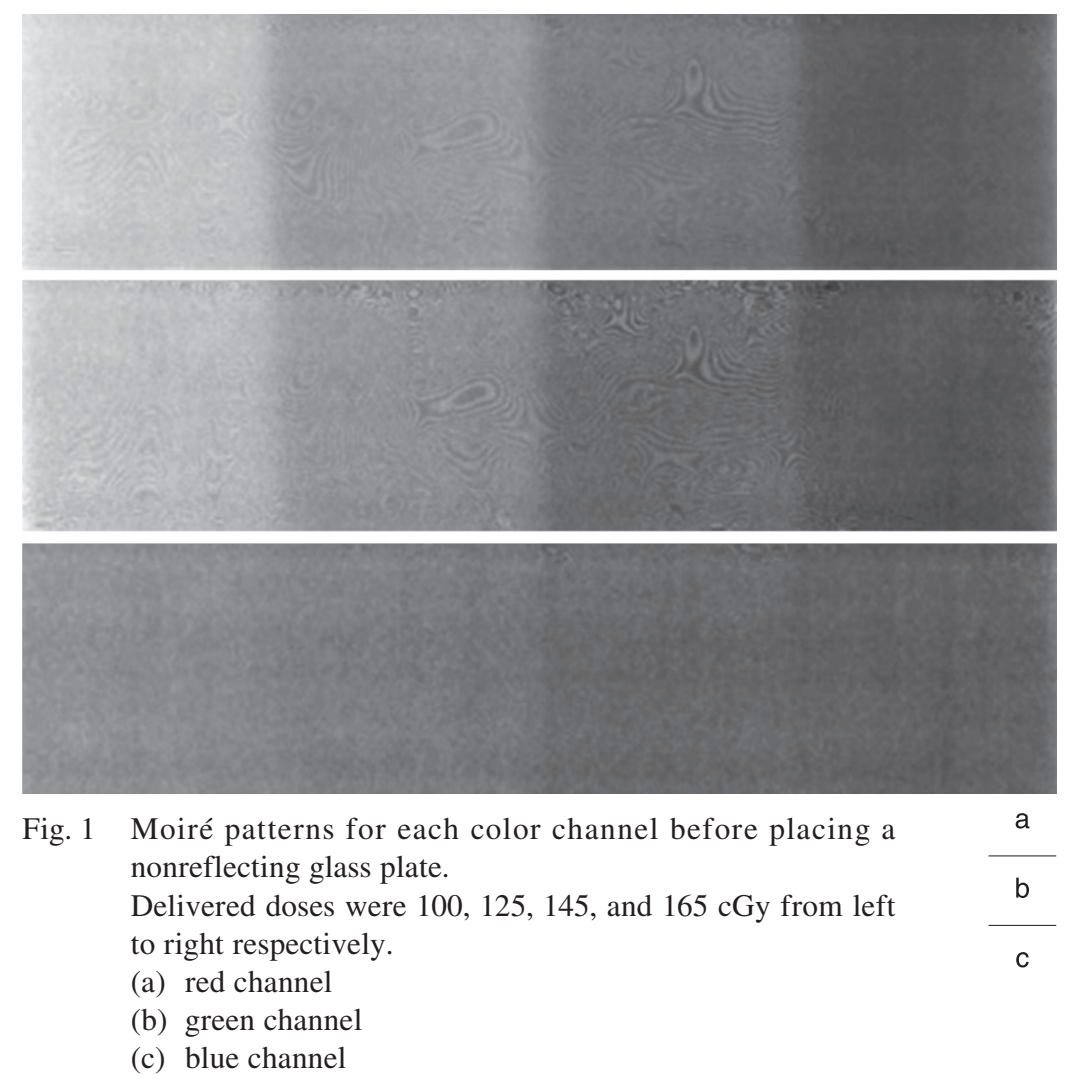

下, normal). 2)スキャナガラス天板の上に EBT2 フィ ルムを置き，その上から $2 \mathrm{~mm}$ 厚の無反射ガラス(六切 サイズ、ジャプル・コーポレーション, Japan)を配置 (以下, glass-light side), この配置は上流の光源側に モアレ対策を行っている．3）スキャナガラス天板の上 に $2 \mathrm{~mm}$ 厚の無反射ガラス, その上に EBT2 フィルムを 置き, さらに $2 \mathrm{~mm}$ 厚の透明ガラスを配置(以下, glassdetector side), この配置は下流の受光部側にモアレ対 策を行っている，各測定において $\mathrm{EBT2}$ フィルムのス キャン方向および表裏は同一とした.

まず，収集波長域の違いによるモアレの発生状況を 確認するため, normal の測定配置にて RGB のスキャン データを収集した，次に，EBT2 フィルムのスキャンに 用いられる red チャンネルと greenチャンネルの波長域 について，3種類の測定配置でスキャンを行い，モアレ の発生状況を定性的に評価した。

\section{2. 結 果}

Normal 配置に扔ける収集波長域の違いとモアレの発 生状況を Fig. 1 に示す. (a)red チャンネルと(b)green チャンネルでモアレが認められ，(c)blue チャンネルでは モアレは認められない, また, redチャンネルと green チャンネルでは, greenチャンネルの方がモアレが強調 される傾向にあった．ISP 社によると，EBT2 の収集波長
域は，0.01〜10 Gy は red チャンネルを使用し，10〜40 Gy は green チャンネルを使用することが推奨されている。 Blue チャンネルは, モアレは発生しないものの十分なコ ントラストを得ることができないため, スキャンには使 用できない。

次に，3 種類の測定配置でスキャンを行ったときのモ アレの発生状況を, Fig. 2, 3 に示す. Fig. 2 は red チャ ンネル, Fig. 3 は greenチャンネルの結果である. 両者 とも同様の傾向を示し, normal および glass-light side の 配置ではモアレの発生を認めた。また, glass-detector sideではモアレの発生を認めず，すべてのモアレを除 去することができた。

\section{3. 考 察}

本報告では, 透過型 RC-film に拐けるモアレ除去の 測定配置について検討を行った，収集波長域の選択に よってモアレの発生状況は変化するが，スキャナの受 光部側にモアレ除去対策を行うことで，モアレをすべて 除去することができた，モアレ除去法およびモアレ除去 法が測定結果に与える影響については, 辰己らの報告 に詳細が述べられている4)，特に注意すべき点は，無反 射ガラス等を挿入することによって, 得られる濃度が変 化するため，特性曲線取得を含むすべての条件で，同 じ測定配置としなければならない点と考えられる. 

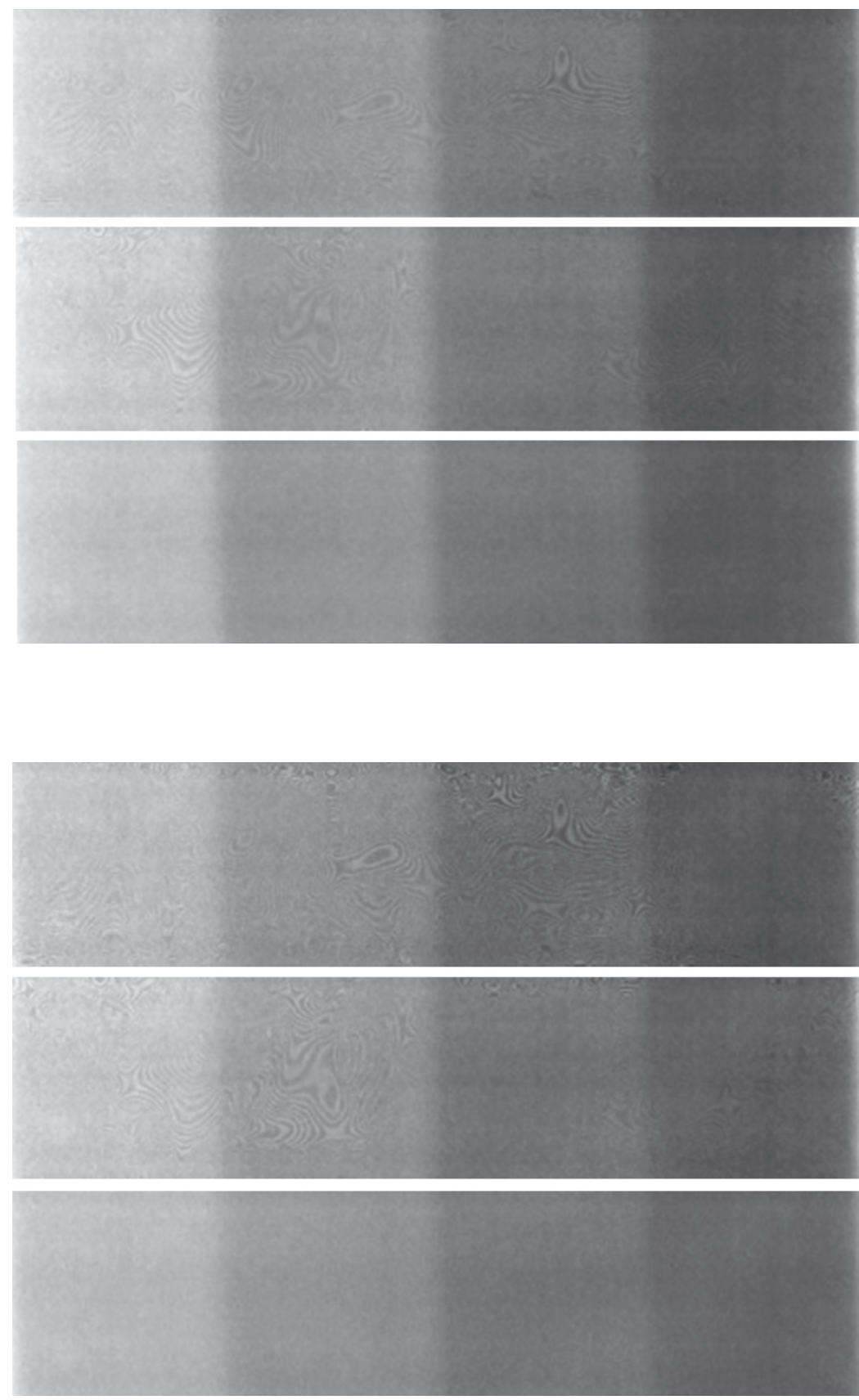

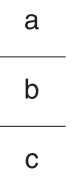

Fig. 2 Moiré patterns for the red channel under three different conditions.

Delivered doses were 100, 125, 145, and 165 cGy from left to right respectively.

(a) before placing a nonreflecting glass plate

(b) after placing a nonreflecting glass plate on the light emitting side

(c) after placing a nonreflecting glass plate on the detector side

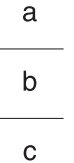

Fig. 3 Moiré patterns for the green channel under three different conditions.

Delivered doses were 100, 125, 145, and 165 cGy from left to right respectively.

(a) before placing a nonreflecting glass plate

(b) after placing a nonreflecting glass plate on the light emitting side

(c) after placing a nonreflecting glass plate on the detector side

\section{4. 結 語}

透過型 RC-film におけるモアレ除去の測定配置につ いて検討を行った．スキャナの受光部側にモアレ除去対 策を行うことで，モアレをすべて除去することができた。

\section{謝 辞}

本稿をまとめるにあたり，多大なご助言を賜りました 藤田保健衛生大学の林 直樹氏に深く感謝致します。

なお，本研究は日本放射線腫瘍学会平成 $21 \cdot 22$ 年度 研究課題「ラジオクロミックフィルムを用いた IMRT の 線量分布検証に関する指針作成」の助成を受けたもので ある。 


\section{参考文献}

1）宮沢正則. ガフクロミックフィルムを用いた線量分布測定 法. 日放技学誌 2006; 62(10): 1428-1436.

2) 隅田伊織. Gafchromic film type EBT2 の取扱い一使用経験 からみて一。 日放技学誌 2010; 66(10): 1367-1375.

3) International Specialty Products. Gafchromic ${ }^{\circledR}$ EBT2 Selfdeveloping film for radiotherapy dosimetry, 2010.
4）辰已大作，中田良成，正井範尚，他. 反射型 Radiochromic film におけるモアレアーチファクト除去法の検討。日放技学 誌 2010; 66(12): 1569-1576.

5) Low DA, Moran JM, Dempsey JF, et al. Dosimetry tools and techniques for IMRT. Med Phys 2011; 38(3): 1313-1338.

\section{| || || |||||||||||||||||||||||||||||||||||||||||||||| 图表の説明}

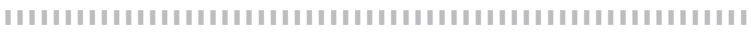

Fig. 1 モアレ対策なしのときの各波長域のモアレ発生状況 左から，100 cGy，125 cGy，145 cGy，165 cGy を照射したデータ (a) red channel, (b) green channel, (c) blue channel

Fig. 2 Red channelに打けるスキャン配置の違いとモアレの発生状況 左から，100 cGy，125 cGy，145cGy，165 cGy を照射したデー夕 (a) normal, (b) glass-light side, (c) glass-detector side

Fig. 3 Green channel におけるスキャン配置の違いとモアレの発生状況 左から，100 cGy，125 cGy，145 cGy，165 cGy を照射したデータ (a) normal, (b) glass-light side, (c) glass-detector side 